\title{
PERBANDINGAN KINERJA INSTRUMEN INVESTASI BERBASIS SYARIAH DENGAN KONVENSIONAL PADA PASAR MODAL DI INDONESIA
}

\author{
Ida Syafrida, Indianik Aminah, Bambang Waluyo ${ }^{1}$
}

\begin{abstract}
The Performance Comparation between sharia instrument performance and conventional syariah. The main objective of investors in investment activities is to get the profit. Similarly, investors in Islamic investment activities want the same things. But often the performance of sharia instruments deemed lower than conventional instruments, so market share Sharia-compliant investment instruments is still minimal. This research doing comparation performance index and mutual fund index between shariah based and conventional based. Based on the results of research that takes samples Islamic instruments of capital markets such as sharia Islamic stocks and sharia mutual funds, it is concluded that the performance of sharia-based investment instruments are not significantly different from the conventional investment instruments, even during the period of research Islamic investment instruments showed slightly better performance.
\end{abstract}

Keywords: Performance, Sharia Islamic Stocks, Sharia Mutual Funds

\begin{abstract}
Abstrak: Perbandingan Kinerja Instrumen Investasi Berbasis Syariab dengan Konvensional di Pasar Modal Indonesia. Tujuan utama investor melakukan kegiatan investasi adalah untuk memperoleh keuntungan. Demikian pula bagi investor kegiatan investasi berbasis syariah, tentu menginginkan hal yang sama. Namun seringkali kinerja instrumen investasi berbasis syariah dipandang lebih rendah dibanding instrumen investasi konvensional, sehingga peminat instrumen investasi berbasis syariah masih minim. Penelitian ini melakukan perbandingan kinerja indeks dan kinerja reksadana antara basis syariah dan basis konvensional. Berdasarkan hasil penelitian yang mengambil sampel instrumen syariah pasar modal dalam bentuk saham syariah dan reksadana syariah ini diperoleh kesimpulan bahwa kinerja instrumen investasi berbasis syariah tidak berbeda signifikan dengan instrumen investasi konvensional, bahkan selama periode penelitian instrumen investasi syariah menunjukkan kinerja sedikit lebih baik.
\end{abstract}

Kata kunci: Kinerja, Saham Syariah, Reksadana Syariah

${ }^{1}$ Diterima: 1 Maret 2014, direvisi: 2 April 2014, disetujui: 16 April 2014 Jurusan Akuntansi, Politeknik Negeri Jakarta, Kampus UI Depok -16425-

Email:sya_frida@yahoo.com,ndianikmashuri@gmail.com, bamwaluyo@yahoo.co.id 


\section{PENDAHULUAN}

Investasi sering diartikan sebagai kegiatan menyisihkan sebagian danauntuk ditempatkan pada sarana investasi dengan harapan dapat memetik nilai ekonomis di kemudian hari. Pada umumnya, investor akan memilih untuk menginvestasikan dananya dengan pertimbangan-pertimbangan finansial, yaitu mempertimbangkan imbal hasil (return) dan risiko (risk) semata. Secara teori, terhadap investasi yang lebih berisiko, investor akan mengharapkan return yang lebih tinggi. Akan tetapi ada pula investor yang dalam kegiatan investasinya tidak semata-mata mempertimbangkan aspek finansial namun juga mempertimbangkan nilai-nilai yang dianutnya, seperti ajaran agama. Investor yang demikian akan menolak berinvestasi pada perusahaan yang menghasilkan prooduk atau aktivitas bisnisnya bertentangan dengan prinsip agama. Di Indonesia yang mayoritas penduduknya beragama Islam mulai dikembangkan investasi berbasis syariah, dimana investasi tersebut mengintegrasikan nilai-nilai agama yang dianut dalam kegiatan investasi dengan cara melakukan proses seleksi (screening) dalam memilih instrumeninstrumen investasinya. Salah satu sarana dalam berinvestasi sesuai prinsip Islam adalah melalui pasar modal syariah.

Kemunculan pasar modal syariah pertama kali di Indonesia ditandai dengan diluncurkannya Danareksa Syariah oleh Danareksa Investment Management pada Juli 1997. Danareksa syariah merupakan reksadana saham yang pertama kali secara eksplisit menyatakan investasinya bersifat syariah. Pada akhir tahun 2000, PT Bursa Efek Jakarta bekerja-sama dengan Danareksa Management Indonesia mengeluarkan Jakarta Islamic Index (JII) yang merupakan indeks dari 30 saham paling likuid dan memenuhi kriteria syariah sesuai ketentuan Dewan Syariah Nasional (DSN). Sedangkan Indeks Saham Syariah Indonesia (ISSI) yang menggambarkan kinerja seluruh saham syariah di Indonesia baru diluncurkan pada 12 Mei 2011. Indonesia dinyatakan secara resmi memiliki Pasar Modal Syariah pada tanggal 14 Maret 2003, dimana saham-saham yang diperdagangkan adalah saham-saham yang telah melalui proses screening sesuai dengan kriteria syariah dengan batasan maksimal hutang ribawi $45 \%$ dari modal. Dengan kriteria tersebut sekaligus sebagai saringan bagi kesehatan perusahaan, karena mitigasi pembiayaan dari bank syariah lebih jelas dalam menyeleksi objek pembiayaan. Kemudian dari sisi modal, perusahaan yang memiliki modal sendiri lebih dominan dibanding hutangnya, maka perusahaan tersebut akan memiliki tingkat kesehatan keuangan uang lebih tinggi daripada yang tidak.

Dukungan (political will) dari regulator untuk mempercepat akselerasi industri keuangan syariah telah dilakukan seperti dengan disahkannya Undang-Undang Surat Berharga Syariah Nasional (UU SBSN). Kemudian disusul dengan diterbitkannya 
Sukuk Negara untuk pertama kali di awal semester II tahun 2008dengan underlying asset barang milik Negara. Dengan adanya akselerasi instrumen syariah, membuka peluang bagi instrumen reksadana syariah sebagai instrumen portofolio investasi syariah untuk berkembang. Secara keseluruhan, berdasarkan data statistik BapepamLK Desember 2011 sampai dengan akhir tahun 2011 NAB reksadana syariah mengalami peningkatan jumlah NAB sebesar Rp. 5,565 T (3,31\% dari keseluruhan NAB reksadana) dari 22 Manajer Investasi, dengan jumlah produk 50 produk (7,74\%). Demikian pula dengan saham, sampai dengan akhir tahun 2011 sudah terdapat 238 saham yang memenuhi kriteria saham syariah.

Dari data statistik Bapepam Desember mengenai perkembangan indeks di pasar modal Indonesia (Tabel 1) diketahui selama tahun 2011 saham-saham syariah memberikan keuntungan lebih rendah dibandingkan saham-saham lainnya. Dimana berdasarkan perhitungan Indeks saham JII memberikan return 12\%, sedangkan LQ 45=13\%.

Tabel. 1. Perkembangan Indeks di Pasar Modal Indonesia Indeks

\begin{tabular}{lll}
\hline Periode & MLQ45 & JII \\
\hline 2007 & 599.82 & 493.01 \\
2008 & 270.23 & 216.19 \\
2009 & 498.29 & 417.18 \\
2010 & 661.38 & 532.90 \\
2011 & 673.51 & 537.03 \\
Januari & 597.85 & 477.51 \\
Februari & 614.02 & 496.87 \\
Maret & 659.05 & 514.92 \\
April & 680.63 & 528.76 \\
Mei & 682.25 & 531.38 \\
Juni & 690.65 & 536.04 \\
Juli & 729.84 & 567.12 \\
Agustus & 676.26 & 529.16 \\
September & 622.64 & 492.30 \\
Oktober & 675.57 & 530.19 \\
November & 656.41 & 520.49 \\
Desember & 673.51 & 537.03 \\
\hline
\end{tabular}

Sumber: Riset Pasar Modal-Biro RISTI Bapepam-LK

Dari data NAB Reksadana (Tabel 2) yang diperoleh dari data statistik Bapepam-LK menunjukkan return reksadana syariah selama tahun 2010 rata-rata 
3\%, sedangkan return reksadana campuran konvensional rata-rata19\%.

Saat ini, meski instrumen investasi syariah di Indonesia terus menunjukkan pertumbuhannya, namun data Bapepam menunjukkan bahwa secara market share industri keuangan syariah dalam kurun waktu lima tahun terakhir masih dalam kisaran 3\% dari industri keuangan nasional. Salah satu cara untuk meningkatkan market share instrumen investasi berbasis syariah adalah dengan menjaga return syariah ke tingkat yang dapat diterima pasar. Keunggulan prinsip ekonomi syariah yang menekankan pada prinsip keadilan, perlarangan spekulasi, serta pelarangan riba seharusnya berimbas pula pada return yang dihasilkan.

Tabel. 2. Nilai Aktiva Bersih Reksa Dana per Jenis(Rp Milyar)

\begin{tabular}{llll}
\hline Periode & Campuran & Syariah & Total \\
\hline 2007 & $14.232,58$ & 0,00 & $92.190,63$ \\
2008 & $10.002,12$ & 774,22 & $74.065,81$ \\
2009 & $15,657.72$ & $3,671.45$ & $116,732.41$ \\
2010 & $21,988.63$ & $3,763.93$ & $149,099.02$ \\
2011 & & & \\
Jan & $18,431.44$ & $3,640.34$ & $143,017.41$ \\
Feb & $18,924.99$ & $3,672.07$ & $145,423.83$ \\
Mar & $20,065.62$ & $3,802.54$ & $150,778.78$ \\
Apr & $20,176.60$ & $3,842.17$ & $153,686.52$ \\
Mei & $20,231.85$ & $3,844.51$ & $155,927.97$ \\
Juni & $21,297.37$ & $3,845.46$ & $157,059.21$ \\
Juli & $20,130.38$ & $3,831.24$ & $157,690.78$ \\
Agt & $32,943.59$ & $3,701.02$ & $180,872.12$ \\
Sept & $19,595.48$ & $3,550.45$ & $154,528.94$ \\
Okt & $20,923.87$ & $3,688.89$ & $162,484.11$ \\
Nov & $20,589.99$ & $3,691.41$ & $162,942.09$ \\
Des & $21,713.15$ & $3,766.86$ & $168,236.89$
\end{tabular}

Sumber: Riset Pasar Modal-Biro RISTI Bapepam-LK

Berdasarkan penelitian Ridho (2008), menghasilkan kesimpulan bahwa perbandingan rata-rata kinerja reksadana konvensional dengan reksadana syariah pada jangka panjang menunjukkan bahwa rata-rata kinerja ketiga indeks, terhadap kedua reksadana tersebut tidak berbeda secara signifikan. Sedangkan penelitian Sufianti (2003) dengan menggunakan periode data jangka pendek menunjukkan bahwa rata-rata return indeks JII tidak berbeda secara signifikan dengan rata-rata indeks LQ-45. Penelitian ini ingin fokus meneliti perbedaan kinerja investasi 
syariah dengan investasi konvensional pada jangka menengah (3 tahun) sebagai periode investasi yang moderat.

\section{TINJAUAN PUSTAKA}

Pasar modal syariah secara sederhana dapat diartikan sebagai pasar modal yang menerapkan prinsip-prinsip syariah dalam kegiatan transaksi ekonomi dan terlepas dari hal-hal yang dilarang oleh syariat seperti: unsur riba, perjudian, bersifat spekulasi dan lain-lain. Pasar modal syariah secara prinsip sangat berbeda dengan pasar modal konvensional. Sejumlah instrumen syariah sudah diterbitkan di pasar modal Indoneisa seperti dalam bentuk saham dan obligasi dengan kriteria tertentu yang sesuai dengan prinsip syariah (Al Arif, 2011)

Menurut Fatwa DSN-MUI No. 40/DSN-MUI/X/2003 yang dimaksud dengan pasar modal syariah adalah pasar modal yang seluruh mekanisme kegiatannya terutama mengenai emiten, jenis efek yang diperdagangkan dan mekanisme perdagangannya telah sesuai dengan prinsip-prinsip syariah. Sedangkan yang dimaksud dengan efek syariah adalah efek sebagaimana dimaksud dalam peraturan perundang-undangan di bidang Pasar Modal yang akad, pengelolaan perusahaan, maupun cara penerbitannya memenuhi Prinsip-prinsip syariah. Adapun yang dimaksud dengan Prinsip-prinsip syariah adalah prinsip yang didasarkan oleh syariah ajaran Islam yang penetapannya dilakukan oleh DSN-MUI melalui fatwa.

Pasar modal syariah secara khusus memperjualbelikan efek syariah. Efek syariah adalah efek yang akad, pengelolaan perusahaan, maupun cara penerbitannya memenuhi prinsip-prinsip syariah yang didasarkan atas ajaran Islam yang penetapannya dilakukan oleh DSN-MUI dalam bentuk fatwa. Secara umum ketentuan penerbitan efek syariah haruslah sesuai dengan prinsip syariah di pasar modal. Prinsip-prinsip syariah di pasar modal adalah prinsip-prinsip hukum Islam dalam kegiatan di bidang pasar modal berdasarkan fatwa Dewan Syariah Nasional Majelis Ulama Indonesia (DSN-MUI), baik fatwa DSN-MUI yang ditetapkan dalam peraturan Bapepam dan LK maupun fatwa DSN-MUI yang telah diterbitkan sebelum ditetapkannya peraturan Bapepam dan LK.

Sampai saat ini, efek-efek syariah menurut Fatwa DSN MUI No.40/DSNMUI/X/2003 tentang Pasar Modal mencakup Saham Syariah, Obligasi Syariah, Reksa Dana Syariah, Kontrak Investasi Kolektif Efek Beragun Aset (KIK EBA) Syariah, dan surat berharga lainnya yang sesuai dengan prinsip-prinsip syariah. Belakangan, instrumen keuangan syariah bertambah dalam fawa DSN-MUI Nomor: 65/DSN-MUI/III/2008 tentang Hak Memesan Efek Terlebih Dahulu (HMETD) Syariah dan Fatwa DSN-MUI Nomor: 66/DSN-MUI/III/2008 tentang Waran Syariah pada tanggal 6 Maret 2008. 


\section{METODE}

Penelitian ini melakukan perbandingan kinerja indeks dan kinerja reksadana antara basis syariah dengan basis konvensional.Perbandingan indeks dilakukan antara Jakarta Islamic Indeks (JII) sebagai proxi investasi syariah dengan indeks LQ 45 sebagai proxi investasi konvensional.Periode pengamatan yang digunakan adalah tahun 2008 sampai dengan 2011.

Perbandingan indeks dilakukan dengan membandingkan total return serta rata-rata return bulanan dari masing-masing indeks, untuk kemudian dilakukan pengujian dengan menggunakan uji-t antara JII dengan LQ-45. Dengan demikian dapat diketahui apakah terdapat perbedaan yang signifikan antara rata-rata return bulanan JII dengan rata-rata return bulanan LQ-45. Return bulanan dari masingmasing indeks diperoleh dari persamaan:

$$
\text { Return bulanan }=\frac{\text { indeks } \mathrm{t}-\text { indeks } \mathrm{t}-1}{\text { indeks } \mathrm{t}-1}
$$

indeks $\mathrm{t}=$ indeks pada bulan ke-t

indeks $\mathrm{t}-1$ = indeks pada bulan sebelumnya

Hipotesa yang diajukan dari perbandingan indeks ini adalah:

Ho : $\quad$ tidak terdapat perbedaan yang signifikan antara kinerja indeks saham-saham syariah dengan kinerja indeks saham-saham konvensional

H1 : terdapat perbedaan yang signifikan antara kinerja indeks saham-saham syariah dengan kinerja indeks saham-saham konvensional

Perbandingan kinerja reksadana dilakukan terhadap satu wakil reksadana syariah dan satu wakil reksadana konvensional dan untuk menghindari bias karena perbedaan kemampuan pengelolaan dari manajer investasi, maka digunakan Reksadana Syariah (basis syariah) dan Reksadana Campuran (basis konvensional) yang dikelola oleh manajer investasi yang sama, yaitu PT Danareksa. Perbandingan juga dilakukan terhadap rata-rata return bulanan dari setiap reksadana dengan menggunakan persamaan berikut:

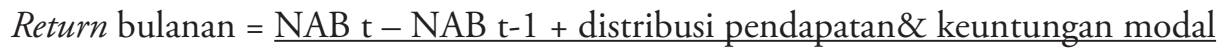
NAB t-1

$\mathrm{NAB} \mathrm{t}=$ Nilai Aktiva Bersih pada bulan ke- $\mathrm{t}$

NAB t-1 = Nilai Aktiva Bersih pada bulan sebelumnya

Setelah itu, kinerja reksadana diukur dengan model Sharpe.Menurut 
Sharpe, kinerja reksadana dapat diprediksi dengan menggunakan dua ukuran, yaitu expected rate of return (ER) yaitu return rata-rata dan predicted variability of risk yang diekspresikan sebagai deviasi standar return $(\sigma)$. Reksadana layak dibeli jika memiliki excess return ( $\mathrm{Rp}-\mathrm{Rf})$ yang bernilai positif. Berikut rumus indeks Sharpe:

$$
\mathrm{R} / \mathrm{V} s=\frac{(\mathrm{Rp}-\mathrm{Rf})}{\sigma \mathrm{p}}
$$

$\begin{array}{ll}\mathrm{R} / \mathrm{Vs} & =\text { reward to variability ratio } \\ \mathrm{Rp} & =\text { average return portfolio } \\ \mathrm{Rf} & =\text { risk free rate } \\ \sigma \mathrm{p} & =\text { deviasi standar return portofolio }\end{array}$

Ho.1 : tidak terdapat perbedaan yang signifikan antara kinerja reksadana syariah dengan kinerja reksadana konvensional.

H1.2 : terdapat perbedaan yang signifikan antara kinerja reksadana syariah dengan kinerja reksadana konvensional

Penelitian ini menggunakan data-data indeks JII dan indeks LQ-45 yang diperoleh dari Bursa Efek Indonesia (BEI).Data-data lain adalah NAB Reksadana Syariah dan Reksadana Campuran dari PT Danareksa. Metode pengumpulan data empiris dan keterangan-keterangan yang berkaitan dengan permasalahan tersebut, dilakukan melalui studi kepustakaan dan konsultasi dengan pihak PT Danareksa. Data-data yang akan dianalisis menggunakan data sekunder berupa laporan publikasi PT BEI dan PT Danareksa pada periode 2008 sampai dengan 2011. Untuk pengujian hipotesis dari data-data tersebut digunakan metode uji beda ratarata (uji-t)dengan menggunakan bantuan program SPSS.

\section{Perbandingan Kinerja Indeks Syariah dan Indeks Konvensional}

Penilaian kinerja indeks dilakukan dengan cara menilai return investasi bulanan terhadap JII dan LQ-45 selama periode 1 Januari 2010 sampai dengan 31 Oktober 2012 yang diperoleh dari data harian JII dan LQ-45. LQ-45 dan JII merupakan indeks bagi saham-saham liquid berkapitalisasi pasar besar, namun JII hanya diambil dari Daftar Saham Syariah yang telah melalui proses screening dalam hal kehalalannya oleh Dewan Syariah Nasional Majelis Ulama Indonesia (DSNMUI). Untuk itu JII dipilih sebagai proxy mewakili investasi pada saham syariah. Dari data, antara JII dengan LQ-45 dapat dikatakan kedua indeks memiliki trend yang sama dalam keseluruhan periode penelitian. Periode dengan return indeks tertinggi berada di bulan Agustus-September 2010 dan terendah di bulan Januari 2011. 


\section{Perbandingan Kinerja Reksadana Syariah dan Reksadana Konvensional}

Penilaian kinerja indeks dilakukan dengan cara menilai reward to variability berdasarkan Indeks Sharpe $(\mathrm{R} / \mathrm{Vs})$ yang diperoleh dari return investasi bulanan Reksadana syariah berimbang (RDSB) dan reksadana anggrek (RDAN) selama periode 1 Januari 2010 sampai dengan 31 Oktober 2012 yang diperoleh dari data harian JII dan LQ-45.

Dipilihnya kedua reksadana yang sama-sama dikelola oleh perusahaan sekuritas yang sama, yaitu PT DIM dimaksudkan agar kekhawatiran adanya kesalahan (misleading) sebagai akibat dari faktor manajemen dan keputusan investasi dapat dihilangkan. Kedua reksadana tersebut juga sama-sama reksadana berjenis campuran, sehingga dapat diperbandingkan secara langsung.

Dari data, return bulanan dari RDSB terlihat cenderung flat, artinya tidak memiliki kenaikan/penurunan yang berarti, sedangkan gambar R/Vs RDSB lebih terlihat dinamisasinya dengan angka tertinggi berada pada periode Oktober 2011, walaupun kecenderungan terakhir mengalami penurunan dengan angka terendah selama periode penelitian. Berdasarkan data, terlihat trend return yang datar, tidak terlihat jelas kenaikan/penurunannya, sehingga dapat dikatakan return cenderung stabil. Trend R/Vs sangat terlihat kenaikan/penurunannya, dimana R/Vs tertinggi pada periode Oktober 2011 dan di akhir periode penelitian trend R/Vs mengalami penurunan sampai pada posisi terendah.

Dari data terlihat kecenderungan trend kenaikan/penurunan kinerja yang hampir sama selama periode penelitian antara reksadana syariah berimbang dengan reksadana anggrek. Namun, jika dilihat lebih cermat, maka akan nampak bahwa R/ Vs RDSB lebih sering berada diatas posisi R/Vs RDAN. Jika ingin dikatakan bahwa kinerja reksadana syariah berimbang sedikit lebih baik daripada kinerja reksadana anggrek. Hal ini sesuai dengan karakteristik reksadana syariah yang merupakan portofolio efek syariah dengan proses seleksi yang lebih ketat dibandingkan efek konvensional, sehingga hasil investasi diharapkan lebih baik dari sisi kehalalan maupun imbal hasilnya.

Namun demikian adanya sedikit perbedaan tidak dapat langsung disimpulkan bahwa memang ada perbedaan antara kinerja investasi syariah dengan investasi konvensional, melainkan perlu dilakukan pengujian lebih lanjut dengan alat-alat statistik untuk membuktikan hipotesis yang telah dibuat sebelumnya.

\section{Pengujian Hipotesis terhadap Perbandingan Kinerja Indeks}

Adanya perbedaan terhadap cara pemilihan saham-saham yang masuk dalam kelompok indeks JII yang melalui proses penyaringan terlebih dahulu dalam hal kehalalannya dengan pemilihan saham-saham dalam kelompok indeks LQ-45 
menimbulkan dugaan adanya perbedaan antara kinerja JII sebagai wakil indeks saham-saham syariah dengan kinerja LQ-45 sebagai wakil indeks saham-saham konvensional dalam penelitian ini.

Hipotesa yang diajukan dari perbandingan indeks ini adalah:

Ho : tidak terdapat perbedaan yang signifikan antara kinerjaindeks saham-saham syariah dengan indeks saham-saham konvensional

H1 : terdapat perbedaan yang signifikan antara kinerja indeks saham-saham syariah dengan indeks saham-saham konvensional

Pengujian dilakukan terhadap angka return bulanan antara JII dengan LQ45 dengan testing hipotesis perbedaan dua rata-rata (two different mean) dengan significancy level $5 \%$.

Setelah dilakukan pengujian dengan software SPSS, maka hasil output adalah sebagai berikut:

\section{HASIL OUTPUT SPSS PENGUJIAN HIPOTESIS JII DAN LQ-45 Group Statistics}

\begin{tabular}{llrrrr}
\hline & Group & $\mathrm{N}$ & \multicolumn{1}{c}{ Mean } & Std. Deviation & \multicolumn{1}{c}{ Mean } \\
\hline $\begin{array}{l}\text { Average Return } \\
\text { Bulanan }\end{array}$ & JII & 34 & .000618 & .0023309 & .0003997 \\
\cline { 2 - 6 } & LQ45 & 34 & .000694 & .0024279 & .0004164 \\
\hline
\end{tabular}

\section{Independent Samples Test}

\begin{tabular}{|c|c|c|c|c|c|c|c|c|c|c|}
\hline & & \multicolumn{2}{|c|}{$\begin{array}{l}\text { Levene's Test } \\
\text { for Equality of } \\
\text { Variances }\end{array}$} & \multicolumn{7}{|c|}{ t-test for Equality of Means } \\
\hline & & \multirow{2}{*}{$\begin{array}{c}\mathrm{F} \\
\text { Lower }\end{array}$} & \multirow{2}{*}{$\begin{array}{l}\text { Sig. } \\
\text { Upper }\end{array}$} & \multirow{2}{*}{$\begin{array}{c}\mathrm{t} \\
\text { Lower }\end{array}$} & \multirow{2}{*}{$\begin{array}{c}\text { df } \\
\text { Upper }\end{array}$} & \multirow{2}{*}{$\begin{array}{c}\text { Sig. } \\
\text { (2-tailed) } \\
\text { Lower }\end{array}$} & \multirow{2}{*}{$\begin{array}{c}\text { Mean } \\
\text { Difference } \\
\text { Upper }\end{array}$} & \multirow{2}{*}{$\begin{array}{c}\text { Std. Error } \\
\text { Difference } \\
\text { Lower }\end{array}$} & \multicolumn{2}{|c|}{$\begin{array}{l}95 \% \text { Confidence } \\
\text { Interval of the } \\
\text { Difference }\end{array}$} \\
\hline & & & & & & & & & Upper & Lower \\
\hline \multirow{2}{*}{$\begin{array}{l}\text { Return } \\
\text { Bulanan }\end{array}$} & $\begin{array}{l}\text { Equal } \\
\text { variances } \\
\text { assumed }\end{array}$ & .029 & .865 & -.132 & 66 & .895 & -.0000765 & .0005772 & -.00122 & .001076 \\
\hline & $\begin{array}{l}\text { Equal } \\
\text { variances } \\
\text { not assumed }\end{array}$ & & & -.132 & 65.891 & .895 & -.0000765 & .0005772 & -.00122 & .001076 \\
\hline
\end{tabular}


Dari tabel kelompok statistik pada Tabel diatas diketahui besar sampel untuk setiap group adalah 34 dengan purata (mean) JII = 0,000618 dan LQ-45 = 0,000694, simpangan baku (std deviation) JII = 0,003997 dan LQ-45 = 0,004164.

Dari hasil Levene's Test yang ditujukkan pada tabel uji t dua sampel independen (independent sample t test) terdapat $\mathrm{p}$ value $=0,865$ lebih besar dari $\bigotimes=$ 0,05 sehingga Ho tidak dapat ditolak. Dengan demikian asumsi kedua varians sama besar terpenuhi, dengan kata lain tidak terdapat perbedaan yang signifikan antara kinerja JII dengan kinerja LQ-45.

\section{Pengujian Hipotesis terhadap Perbandingan Kinerja Reksadana}

Adanya perbedaan terhadap cara pemilihan porofolio efek yang masuk dalam kelompok reksadana syariah berimbang yang terdiri dari efek saham syariah, sukuk, maupun surat berharga berbasis syariah lainnya dengan pemilihan portofolio efek dalam kelompok reksadana anggrek menimbulkan dugaan adanya perbedaan antara kinerja reksadana syariah berimbang (RDSB) sebagai wakil investasi pada instrumen syariah dengan kinerja reksadana anggrek (RDAN) sebagai wakil investasi pada instrumen konvensional dalam penelitian ini.

Hipotesa yang diajukan dari perbandingan indeks ini adalah:

Ho : tidak terdapat perbedaan yang signifikan antara kinerja reksadana syariah dengan kinerja reksadana konvensional.

H1 : terdapat perbedaan yang signifikan antara kinerja reksadana syariah dengan kinerja reksadana konvensional

Pengujian dilakukan terhadap angka reward to variabilityRDSB denganreward to variability RDAN dengan testing hipotesis perbedaan dua rata-rata (two different mean) dengan significancy level 5\%.

Setelah dilakukan pengujian dengan software SPSS, maka hasil output adalah sebagai berikut:

\section{HASIL OUTPUT SPSS PENGUJIAN HIPOTESIS RDSB DAN RDAN}

Group Statistics

\begin{tabular}{|c|c|c|c|c|c|}
\hline & Group & $\mathrm{N}$ & Mean & $\begin{array}{c}\text { Std. } \\
\text { Deviation }\end{array}$ & $\begin{array}{c}\text { Std. Error } \\
\text { Mean }\end{array}$ \\
\hline \multirow[t]{2}{*}{ Reward to Variability } & RDSB & 34 & -.585900 & .2685860 & .0460621 \\
\hline & RDAN & 34 & -.685541 & .3296666 & .0565374 \\
\hline
\end{tabular}




\section{Independent Samples Test}

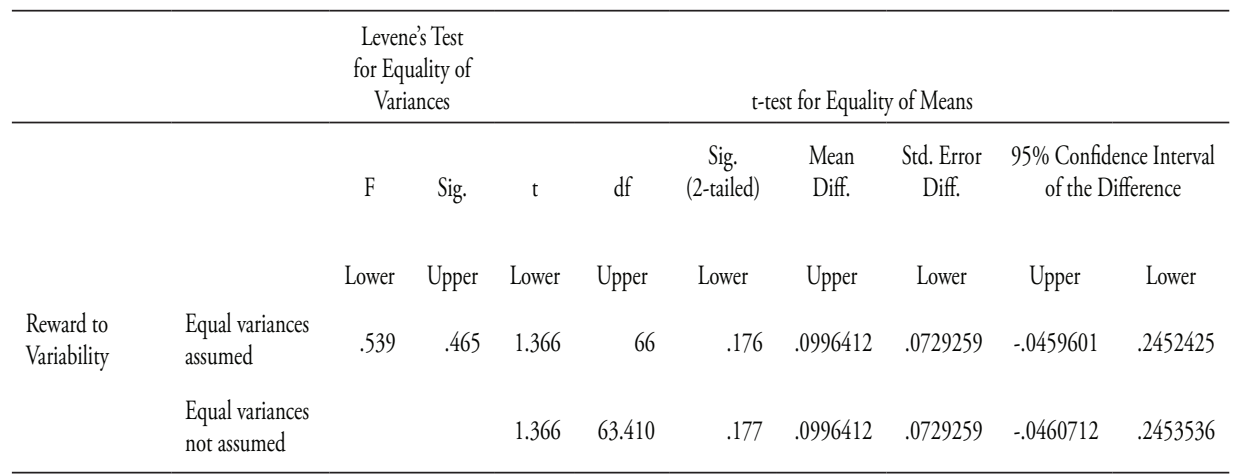

Dari tabel kelompok statistik pada tabel diatas diketahui besar sampel untuk setiap group adalah 34 dengan purata (mean) $\mathrm{RDSB}=0,5859$ dan $\mathrm{RDAN}=$ 0,685541 , simpangan baku (standard deviation) $\mathrm{RDSB}=0,0460621$ dan RDAN $=0,0565374$.

Dari hasil Levene's Test yang ditujukkan pada tabel uji t dua sampel independen(independent samples $t$ test) terdapat $\mathrm{p}$ value $=0,465$ lebih besar dari $\mathbb{\nabla}=$ 0,05 sehingga Ho tidak dapat ditolak. Dengan demikian asumsi kedua varians sama besar terpenuhi, dengan kata lain tidak terdapat perbedaan yang signifikan antara kinerja reksadana syariah dengan kinerja reksadana konvensional.

\section{SIMPULAN}

Berdasarkan hasil yang didapat menunjukkan bahwa kinerja JII dengan kinerja LQ-45 tidak terdapat perbedaan yang signifikan, demikian pula antara kinerja reksadana syariah dengan kinerja reksadana konvensional. Hal ini menunjukkan bahwa instrumen berbasis syariah tidak kalah menguntungkan jika dibanding dengan instrumen berbasis konvensional. Bahkan jika diamati lebih cermat selama periode pengamatan terlihat kinerja reksadana syariah sedikit lebih baik daripada kinerja reksadana konvensional.

Untuk itu bagi investor yang menginginkan cara berinvestasi sesuai prinsip Islam yaitu menghindari produk dan transaksi haram, bathil, maisyir, gharar, dan ribasaat ini tidak perlu ragu. Investor tersebut dapat menempatkan dananya pada instrument pasar modal berbasis syariah, seperti saham syariah, sukuk, dan reksadana syariah, karena dijamin kehalalan produknya dan memiliki imbal hasil yang tidak kalah dari instrumen konvensional. 


\section{PUSTAKA ACUAN}

Achsien, I.H. 2000. Investasi Syariah di Pasar Modal Menggagas Praktek Manajemen Portofolio Syariah. Jakarta: Gramedia Pustaka Utama.

Ahmad, K. 2004. Dasar-Dasar Manajemen Investasi dan Portofolio Edisi Revisi. Jakarta: Rineka Cipta.

Al Arif, M. N. R. 2011. Lembaga Keuangan Syariah: Kajian Teoritis Praktis. Bandung: Pustaka Setia.

Anoraga, P. \& P. Pakarti. 2006. Pengantar Pasar Modal Edisi Revisi. Jakarta: Rineka Cipta.

Anwar, T.F. 2006. Kinerja Investasi Saham, Obligasi, dan Reksadana PT Asuransi Jasa Indonesia Berdasarkan Metode Sharpe dan Optimalisasi Portofolio (Tesis). Jakarta: Universitas Indonesia.

Darmadji, T. \& H.M. Fakhruddin. 2001. Pasar Modal Indonesia Pendekatan Tanya Jawab. Jakarta: Salemba Empat.

Deniansyah, B. 2001. Optimalisasi Portofolio Investasi Reksadana Syariah (Tesis). Jakarta: Universitas Indonesia.

Halim, A. 2005. Analisis Investasi Edisi Kedua. Jakarta: Salemba Empat.

Harianto F. \& S. Sudomo. 1998. Perangkat dan Teknis Analisis Investasi di Pasar Modal Indonesia. Jakarta: Bursa Efek Indonesia.

Huda, N. \& M.E. Nasution. 2007. Investasi pada Pasar Modal Syariah (Edisi Revisi). Jakarta: Kencana.

Husnan, S. 2001. Dasar-dasar Teori Portofolio dan Analisa Sekuritas (Edisi ketiga). Yogyakarta: UPP AMP YKPN.

Liestyowati. 2000. Analisis Faktor-Faktor yang Mempengaruhi Return Saham di BEJ Analisa Periode Sebelum Krisis dan Periode Selama Krisis (Tesis). Jakarta: Universitas Indonesia.

Nachrowi, D.N. \& H. Usman. 2005. Penggunaan Teknik Ekonometri. Jakarta: PT Raja Grafindo Persada.

Ridho, A. 2008. Perbandingan Kinerja Reksadana Konvensional dan Syariah dengan Indeks Sharpe, Treynor, dan Jensen (Periode Tahun 2003-2007) (Tesis). Jakarta: Universitas Indonesia.

Sufianti, Y. 2003. Analisa Kinerja Investasi Etis di Indonesia Periode 2001-2002 (Studi Kasus Perbandingan Kinerja Investasi Konvensional dengan Investasi Syariah di Indonesia) (Tesis). Jakarta: Universitas Indonesia.

Sulistiowati, I. 2004. Analisis Hasil Investasi dan Kinerja Portofolio Reksadana PT Asuransi Jasindo (Tesis). Jakarta: Universitas Indonesia.

Usman, M. 1997. Bunga Rampai Reksadana. Jakarta: Balai Pustaka.

Warsini, S. 2009. Manajemen Investasi. Jakarta: Semesta Media. 